\title{
PENGARUH PENGHARGAAN FINANSIAL, NILAI-NILAI SOSIAL DAN PERTIMBANGAN PASAR KERJA TERHADAP MINAT PEMILIHAN KARIER SEBAGAI AKUNTAN PUBLIK
}

\section{THE INFLUENCE OF FINANCIAL AWARDS, SOCIAL VALUES AND JOB MARKET CONSIDERATIONS AGAINST INTEREST THE SELECTION OF A PUBLIC ACCOUNTANT CAREER}

\author{
A .Lasmana, E. Kustiana \\ Jurusan Akuntansi Fakultas Ekonomi Universitas Djuanda Bogor \\ E-mail: andy.lasmana@unida.ac, hi.erykustiana@gmail.com
}

\begin{abstract}
Career is as a development and progress in either life, occupation or a person's position. A career consists of an order of experience or a series of work held during a person's life of continuity, tranquility and hope to advance in order to create certain attitudes and behaviors. This study aims to determine the effect of financial rewards, social values and job market considerations against interest the selection of a public accountant career. Empirical study at student majoring in accounting S1 at private universities of Bogor. The research population in this study is accounting students of 4 (four) universities in Bogor. Sampling of 288 students was carried out by proportionate stratified random sampling. This research analysis tools using multiple regression analysis. With the hypothesis testing using the F-test and the t-test. The results of the analysis, the conclusion that financial rewards, social values and job market considerations are simultaneously and partially influential in the interest of career selection as a public accountant. This means that the variable financial rewards, social values and job market considerations affect students interest in the selection of careers as public accountants.
\end{abstract}

Keywords: Careers, Job Interests, Public Accountants, Rewards, Social

\begin{abstract}
ABSTRAK
Karier adalah proses perkembangan dan kemajuan pada seseorang, baik pada kehidupan, pekerjaan ataupun jabatan. Karier terdiri dari urutan atau suatu rangkaian pengalaman kerja yang terjadi selama kehidupan seseorang yang berkesinambungan, untuk memperoleh ketentraman dan harapan untuk maju sehingga menciptakan sikap dan perilaku tertentu. Penelitian ini bertujuan untuk mengetahui pengaruh penghargaan finansial, nilai-nilai sosial dan pertimbangan pasar kerja terhadap minat pemilihan karier sebagai akuntan publik. Studi empiris dilakukan pada mahasiswa S1 program studi akuntansi perguruan tinggi swasta di Bogor. Populasi penelitian dalam penelitian ini adalah mahasiswa akuntansi dari 4 (empat) universitas di Bogor. Pengambilan sampel yang berjumlah 288 mahasiswa dilakukan dengan proportionate stratified random sampling. Alat analisis data yang digunakan dalam penelitian ini adalah analisis regresi linier berganda. Dengan pengujian hipotesis menggunakan uji $\mathrm{F}$ dan uji t. Hasil analisis yang dilakukan, diperoleh kesimpulan bahwa penghargaan finansial, nilai-nilai sosial dan pertimbangan pasar kerja berpengaruh secara simultan dan parsial terhadap minat pemilihan karier sebagai akuntan publik. Artinya, variabel penghargaan finansial, nilai-nilai sosial dan pertimbangan pasar kerja mempengaruhi minat mahasiswa dalam pemilihan karier sebagai akuntan publik.
\end{abstract}

Kata Kunci: Akuntan Publik, Karir, Minat Kerja, Penghargaan, Sosial 


\section{PENDAHULUAN}

Menurut data Ikatan Akuntan Indonesia (IAI) jumlah akuntan publik diIndonesia pada tahun 2011 yaitu sebanyak 995 orang, pada tahun 2012 sebanyak 1.016 orang, pada tahun 2013 sebanyak 1.019 orang, dan pada tahun 2014 sebanyak 1.053 orang. Jumlah ini menunjukan bahwa pertumbuhan akuntan publik di Indonesia tidak bertambah secara signifikan dari tahun ketahun, dan jumlah akuntan publik berada di kisaran seribuan ini masih tertinggal jika dibandingkan dengan beberapa Negara ASEAN yang lain. Pada tahun 2012 jumlah akuntan publik di Malaysia tercatat sekitar 2.500 orang, dan di Thailand tercatat sebanyak 6.000 orang, sementara itu tercatat 4.941 orang jumlah akuntanpublik yang berada di Filipina. (http://www.iaiglobal.or.id).

Perkembangan profesi akuntan publik pada saat ini tentu saja searah dengan semakin meningkatnya kebutuhan akan akuntan publik. Namun sayangnya pertumbuhan akuntan publik yang berada di Indonesia justru kian melamban. Hal yang menyebabkan pertumbuhan akuntan publik di Indonesia tidak bertambah secara signifikan menurut Pusat Pembinaan Profesi Keuangan (PPPK) terdapat beberapa hal yang mengakibatkan lulusan akuntansi enggan untuk menjadi seorang akuntanpublik yaitu waktu kerja yang overtime, deadline yang tidak terealisasi, tekanan politik pada perusahaan dan sanksi untuk akuntan publik yang tidak professional (Arismutia,2017).

Selain jumlah, terdapat hal lain yang menjadi permasalahan atau isu yaitu struktur usia dari Akuntan Publik diIndonesia. Berikut tabel data struktur usia akuntan publik di Indonesia menurut data dari Pusat Pembinaan Profesi Keuangan (PPPK) pada tahun 2014:

Tabel 1. Persebaran Usia Akuntan Publik di Indonesia pada Tahun 2014

\begin{tabular}{ccc}
\hline Usia & Jumlah & Persentase \\
\hline$<30$ tahun & 10 orang & $0,94 \%$ \\
\hline 31-39 tahun & 132 orang & $12,54 \%$ \\
\hline 40-49 tahun & 305 orang & $28,97 \%$ \\
\hline
\end{tabular}

\begin{tabular}{ccc}
\hline 50-59 tahun & 273 orang & $25,93 \%$ \\
\hline$>59$ tahun & 333 orang & $31,62 \%$ \\
\hline
\end{tabular}

Sumber: Pusat Pembinaan Profesi Keuangan (PPPK), 2018

Berdasarkan Tabel 1 dapat dilihat struktur usia akuntanpublik di Indonesia pada tahun 2014 menunjukkan struktur usia kurang dari 30 tahun memiliki persetase sebesar $0,94 \%$ lebih rendah dibandingkan dengan struktur usia 30-39 tahun sebesar 12,54\%, 40-49 tahun sebesar 28,97\%, 50-59 tahun sebesar 25,93\%, sedangkan >59 tahun sebesar 31,62\%. Padahal, negara Indonesia memerlukan akuntan publik paling sedikit sekitar 200.000 orang. Jumlah ini adalah rasio minimum yaitu hanya $0,1 \%$ dari jumlah penduduk Indonesia. Hal tersebut merupakan peluang bagi para mahasiswa akuntansi. Bila tidak dipersiapkan sejak dini maka bukan hal yang mustahil jika dimasa depan akuntan public diIndonesia akan sangat bergantung pada tenaga asing dan menjadi penonton di negeri sendiri (Dary dan Ilyas, 2017).

Indonesia pada saat ini memiliki lebih dari 265.000 mahasiwa akuntansi aktif yang berasal dari 589 perguruan tinggi seluruh Indonesia. Menurut data World Bank pada tahun 2014 lulusan mahasiswa akuntansi dari seluruh negara ASEAN rata-rata setiap tahunnya berjumlah 77.330 orang. Indonesia menjadi peringkat pertama terbanyak penghasil lulusan Akuntansi dengan kontribusi $45 \%$ dari jumlah keseluruhan lulusan mahasiswa akuntansi ASEAN, dan setiap tahun Indonesia bisa mencetak kurang lebih 35.000 mahasiswa lulusan akuntansi. Jumlah tersebut menunjukkan bahwa Indonesia mempunyai peluang yang cukup besar untuk menjadi negara dengan profesi akuntan terkuat di regional. Tetapi, dari jumlah tersebut baru sekitar 24.000 orang yang terdaftar sebagai Akuntan Profesional yang bernaung di organisasi profesi Ikatan Akuntan Indonesia (IAI). Saat ini Indonesia jelas sangat membutuhkan strategi yang mumpuni agar 
Akuntan Profesional Indonesia bisa berjaya di regional, apalagi saat ini kita telah memasuki era pasar bebas dalam bentuk Masyarakat Ekonomi Association of Southeast Asian Nations (ASEAN). (http://www.iaiglobal.or.id).

Kota Bogor merupakan salah satu dari berbagai kota di Indonesia yang menjadi pilihan calon mahasiswa untuk melanjutkan pendidikannya, hal ini dibuktikan oleh data yang dipublikasi Badan Pusat Statistik (BPS) Kota Bogor bahwa jumlah mahasiswa di Kota dan Kabupaten Bogor yang berasal dari seluruh program studi pada tahun 2014 sebanyak 49.967 mahasiswa, pada tahun 2015 sebanyak 51.017 mahasiswa, dan pada tahun 2016 sebanyak 55.998 mahasiswa, dengan bermacam-macam pilihan perguruan tinggi yang terdapat di Kota dan Kabupaten Bogor mulai dari Sekolah Tinggi, Universitas hingga Institut. Hal tersebut menunjukan bahwa jumlah mahasiswa setiap tahunnya mengalami peningkatan yang signifikan. Dari beberapa perguruan tinggi tersebut, terdapat perguruan tinggi yang menawarkan program studi akuntansi yang berpotensi untuk menjadikan lulusan program studi akuntansinya menjadi seorang akuntan publik setelah selesai menempuh jenjang pendidikannya. Adapun jumlah mahasiswa akuntansi S-1 yang berstatus aktif di Kota dan Kabupaten Bogor menurut Pangkalan Data Pendidikan Tinggi Kementerian Riset, Teknologi Dan Pendidikan Tinggi (PDDIKTI) yaitu sebanyak 4.031 mahasiswa yang tersebar dibeberapa perguruan tinggi mulai dari Sekolah Tinggi, Universitas hingga Institut, dan hal tersebut menunjukkan bahwa mahasiswa aktif perguruan tinggi program studi S-1 akuntansi di Kota dan Kabupaten Bogor dapat berpotensi besar untuk menjadi seorang akuntan publik setelah selesai menempuh pendidikannya (Harianti,2017).

Hikmah dan Samsul (2020), minat adalah rasa suka atau ketertarikan pada sesuatu hal atau kegiatan, tanpa adanya paksaan dari pihak lain. Iswahyuni (2018) minat merupakan hasil dari proses melihat, pengamatan lalu membandingkan dengan kebutuhan yang diinginkan, yang menyebabkan rasa ketertarikan yang didorong oleh keinginan dari diri sendiri.

Kharismawati, (2015) Karier merupakan hasil dari pengembangan diri seseorang dalam suatu organisasi. Banyak orang berpendapat bahwa karier seseorang adalah "garis tangan" atau nasib, oleh sebab itu tidak perlu orang merencanakan kariernya. Kusuma dan Rizki (2017) berpendapat bahwa karier umumnya diartikan sebagai ide untuk terus bergerak ke atas dalam garis pekerjaan yang dipilih seseorang. Bergerak ke atas berarti mempunyai hak untuk mendapatkan pendapatan yang lebih besar, serta mendapatkan status dan kuasa yang lebih besar.

Faktor penghargaan finansial adalah hal yang dapat dipertimbangkan dalam memilih suatu pekerjaan bagi seseorang. Penghargaan finansial tersebut dipertimbangkan dalam pemilihan karier seseorang, karena tujuan seseorang bekerja yaitu untuk memperoleh penghargaan finansial. Menurut Kwarto, F., \& Saputra (2017) penghargaan finansial merupakan semua pendapatan atas jasa yang diberikan oleh karyawan kepada perusahaan yang dapat berbentuk uang, maupun barang langsung dan tidak langsung. Wijayanti (2001) menyatakan bahwa mahasiswa dalam pememilihan suatu profesi juga mempertimbangkan faktor penghargaan finansial/gaji. Marsudi dan Gustiani (2018) dalam penelitiannya menunjukkan bahwa penghargaan finansial memiliki pengaruh signifiikan terhadap pemilihan karir sebagai akuntan publik.

Pekerjaan akuntan publik memperlukan kondisi lingkungan serta situasi sekitar yang bagus. Nilai-nilai sosial dapat membuat pekerjaan akuntan publik untuk lebih dihargai dan mendapatkan tempat dilingkungan sosial masyarakat. Memiliki rasa perhatian dan kepedulian pada lingkungan sekitar oleh 
seorang akuntan dapat menambah nilai instrinsik dan nilai jual akuntan. Menurut Nuraini (2013: 97) nilai sosial kerja yaitu segala sesuatu yang terdapat disekeliling karyawan dan dapat mempengaruhinya dalam melaksanakan tugas yang dibebankan kepada karyawan tersebut. Nilai-nilai sosial merupakan faktor yang dapat menunjukan kemampuan seseorang pada masyarakat atau dengan kata lain, nilai seseorang dari sudut pandang orangorang yang berada disekitar lingkungannya. Mulyaningsih (2018) di dalam penelitiannya mengemukakan bahwa faktor nilai-nilai sosial dikontrol oleh variabel gender mempunyai pengaruh yang signiifikan terhadap pemilihan karier sebagai akuntan publik. Suyono (2014) dalam penelitiannya menunjukkan bahwa variabel nilai-nilai sosial secara parsial berpengaruh signifikan terhadap pemilihan karier sebagai akuntan publik oleh mahasiswa akuntansi.

Masalah pertimbangan pasar kerja tidak dapat dipungkiri menjadi salah satu pertimbangan pemilihan karir oleh seseorang. Pertimbangan pasar kerja berkaitan erat dengan suatu pekerjaan yang bisa dengan mudah didapatkan pada masa yang akan datang. Suatu pekerjaan yang memiliki pasar kerja yang lebih besar akan sangat diminati dibandingkan dengan pekerjaan yang memiliki pasar kerja yang lebih kecil. Kurniawan, dkk (2015) menyebutkan bahwa rata-rata mahasiswa memilih jurusan akuntansi didasari oleh keinginan untuk menjadi profesional di bidang akuntansi, selain itu mereka

\section{METODE PENELITIAN}

Objek dalam penelitian yang dipilih oleh penulis adalah berkaitan dengan pengaruh Penghargaan Finansial, Nilai-Nilai Sosial dan Pertimbangan Pasar Kerja. Penelitian ini dilakukan pada mahasiswa akuntansi jenjang Strata 1 (S1) di Universitas Djuanda Bogor yang beralamat di Jalan Tol Ciawi Nomor 1, Ciawi, Kabupaten Bogor, Provinsi Jawa Barat, Indonesia 16720. Sekolah Tinggi Ilmu Ekonomi termotivasi dengan menganggap bahwa memiliki pekerjaan sebagai akuntan akan sangat dibutuhkan oleh perusahaan dan organisasi baik yang di Indonesia maupun secara global di masa depan. Kesempatan untuk berkerja di Indonesia sudah dijamin dalam Undang-Undang Dasar (UUD) 1945 pada pasal 27 ayat 2 yaitu "Tiap-tiap warga Negara berhak atas pekerjaan dan penghidupan yang layak". Sukirno (2000: 68) Kesempatan Kerja adalah suatu keadaan tertentu dimana setiap pekerja yang ingin bekerja pada suatu tingkat upah tertentu akan dengan mudah untuk mendapatkan pekerjaan tersebut. Harianti (2017) dalam penelitiannya menunjukkan bahwa variabel pertimbangan pasar kerja memiliki pengaruh signifikan positif terhadap minat menjadi akuntan publik.

Berdasarkan uraian diatas bahwa penelitian ini merupakan penelitian lanjutan dari penelitian-penelitian sebelumnya dengan menguji apakah variabel penghargaan finansial, nilai-nilai sosial dan pertimbangan pasar kerja berpengaruh terhadap minat mahasiswa Strata 1 (S1) jurusan akuntansi perguruan tinggi di Bogor dalam memilih karier sebagai akuntan publik. Maka dari itu dalam penelitian ini penulis tertarik untuk melakukan penelitian dengan judul:

"Pengaruh Penghargaan Finansial, Nilai-Nilai Sosial Dan Pertimbangan Pasar Kerja Terhadap Minat Pemilihan Karier Sebagai Akuntan Publik (Studi Empiris pada Mahasiswa S1 Program Studi Akuntansi Perguruan Tinggi Swasta di Bogor)"

Triguna yang beralamat di Jalan Siliwangi Nomor 97, Kota Bogor, Provinsi Jawa Barat, Indonesia 16142. Universitas Nusa Bangsa yang beralamat diJalan $\mathrm{KH}$. Sholeh Iskandar (Jalan Baru KM 4), Kelurahan Cibadak, Kecamatan Tanah Sareal, Kota Bogor, Provinsi Jawa Barat, Indonesia 16166. Universitas Pakuan yang beralamat di Jalan Pakuan Nomor 1 Ciheuleut, Kecamatan Kota Bogor Tengah, Kota Bogor, Provinsi Jawa Barat 16144. 
Unit analisis dalam penelitian ini yaitu Perguruan Tinggi Swasta di Kota dan Kabupaten Bogor yang terdapat Program Studi Akuntansi Strata 1 (S1) yang berakreditasi "B" dan terdapat mata kuliah Auditing atau Pemeriksaan Akuntansi. Adapun pengambilan sampel didalam penelitian ini dengan menggunakan teknik proportiionate stratified random sampling dan menggunakan rumusslovin sehingga sampel didalam penelitian ini berjumlah 288 mahasiswa.

Metode yang digunakan untuk mengumpulkan data yaitu dengan metode angket (kuesioner). Kuesioner disini menggunakan kuesioner model tertutup karena jawaban sudah tersedia dan pengukurannya menggunakkan skala likert. Sugiyono (2015), skala likert yaitu skala yang dipergunakan untuk mengukur sikap, pendapat, danpersepsi dari seseorang tentang suatu objek atau fenomena tertentu, yang didata dari skala ordinal. Pengolahan data dari kuisioner dapat diukur dengan cara penilaian sebagai berikut:

Tabel 2. Penilaian Kuesioner

\begin{tabular}{cc}
\hline Bobot Nilai & Jawaban Responden \\
\hline 1 & Sangat Tidak Setuju \\
2 & Tidak Setuju \\
3 & Kurang Setuju \\
4 & Setuju \\
5 & Sangat Setuju \\
\hline
\end{tabular}

Sumber : Sugiyono (2013: 137)

Uji validitas digunakan untuk mengukur sah atau valid tidaknya suatu kuesioner (Purwati dan Sari, 2015). Suatu kuesioner bisa dinyatakan valid jika suatu pertanyaan pada kuesioner tersebut mampu mengungkapkan sesuatu yang akan diukur oleh kuesioner tersebut. Sugiyono (2013: 183) untuk menguji validitas maka dihitung koefisien korelasi antara masingmasing skor total dengan menggunaakan rumus korelasi product moment. Item instrument dspst dianggap valid jika koefisien sama dengan atau lebih besar dari 0,3 jika kurang dari 0,3 maka item instrumen tersebut dinyatakan tidak valid. Berikut rumus korelasi Product Moment:

$$
\begin{aligned}
\mathrm{r}_{\mathrm{xy}}= & \frac{N \sum X Y-\left(\sum X\right)\left(\sum Y\right)}{\sqrt{\left(N \sum X^{2}-\left(\sum X\right)^{2}\left(N \sum Y^{2}-\left(\sum Y\right)^{2}\right.\right.}} \\
& \text { Sugiyono (2015), Uji Reliabilitas }
\end{aligned}
$$

adalah pengukuran yang berkali kali menghasilkan data yangsama atau konsisten. Hasil pengujian reliabilitas menunjukan seberapa jauh suatu alat ukur bisa dipercaya atau diandalkan melalui pengujian validitas dan dinyatakan valid. Alat yang digunakan untk mengukur reliabilitas adalah Alpha Cronbach. Suatu variabel dinyatakan reliabel, juka hasil Alpha Cronbach > 0,60 $=$ reliable, hasil Alpha Cronbach $<0,60=$ tidak reliabel. Rumus digunakan untuk Alpha Cronbach adalah.

$$
\mathrm{r}_{\text {hitung }}=\frac{k}{(k-1)}\left(1-\frac{\sum s_{i}^{2}}{s_{i}^{2}}\right)
$$

Teknik yang digunkan untuk menganalisis data yaitu analisis regresi linear berganda menggunakan software SPSS vs 22. Sugiyono (2015), menyatakan bahwa teknik regresi linier berganda (multiple regression analysis) digunakan untuk mengetahui hubungan fungsional antara beberapa varlabel bebas terhadap variabel terikat, dan untuk memprediksi atau meramalkan bagaimana perubahan nilai variabel dependen, jika nilai variabel independen tersebut dinaikan ataupun diturunkan nilainya. Analisis regresi berganda dilakukan untuk mengetahui ada tidaknya pengaruh signifikan antara duaatau lebih variable bebas dengan variable terikat.

Sebelum melakukan pengujian model regresi linier berganda terhadap hipotesis penelitian, terlebih dahulu akan dilakukan pengujian asumsi klasik yaitu: uji normalitas, uji heteroskedastisitas dan uji multikolinearitas.

\section{HASIL DAN PEMBAHASAN}

Jumlah responden yang dijadikan sampel penelitian yaitu 288 responden yang diambil dari masing-masing mahasiswa perguruan tinggi swasta diKota dan Kabupaten Bogor yang terdapat program studi akuntansi Strata 1 (S1) yang berakreditasi "B". Perguruan tinggi 
tersebut terdiri dari Universitas Djuanda Bogor, Universitas Nusa Bangsa, Sekolah Tinggi Ilmu Ekonomi Triguna dan Universitas Pakuan. Untuk menggambarkan karakteristik responden maka dilakukan deskriptif responden berdasarkan atas pengelompokan menurut deskripsi data penelitian, jenis kelamin, usia, dan angkatan. Dibawah ini adalah tabel rekapitulasi dari keseluruhan responden, yaitu sebagai berikut:

Tabel 3. Rekapitulasi Karakteristik Responden

\begin{tabular}{ccc}
\hline $\begin{array}{c}\text { Kriteria } \\
\text { Responden }\end{array}$ & Karakteristik & Persentase \\
\hline Jenis Kelamin & Perempuan & $64 \%$ \\
\hline Usia & $21-23$ tahun & $43 \%$ \\
\hline Angkatan & 2015 & $60,76 \%$ \\
\hline
\end{tabular}

Sumber: Data Diolah 2018

Berdasarkan Tabel tersebut menunjukan bahwa karakteristik responden didalam penelitian ini yaitu didominasi oleh perempuan yakni sebanyak 183 orang, dengan usia responden berkisar antara 21-23 tahun berjumlah 126 orang. Berdasarkan dengan karakteristik tersebut, dapat disimpulkan bahwa mahasiwa S1 program studi akuntansi di Universitas Djuanda Bogor, Universitas Nusa Bangsa, Sekolah Tinggi Ilmu Ekonomi Triguna dan Universitas Pakuan berada pada usia yang produktif yang dianggap telah memahami lebih matang dalam mempertimbangkan pemilihan profesi untuk jenjang karirnya.

Berdasarkan rekapitulasi dari masingmasing jawaban responden, dibawah ini merupakan rekapitulasi dari keseluruhan tanggapan atau jawaban responden, yaitu sebagai berikut:

Tabel 4. Rekapitulasi Tanggapan

\begin{tabular}{lcc}
\multicolumn{1}{c}{ Variabel } & $\begin{array}{c}\text { Nilai Rata- } \\
\text { Rata Score }\end{array}$ & Keterangan \\
\hline $\begin{array}{l}\text { Penghargaan } \\
\text { Finansial }\left(\mathrm{X}_{1}\right)\end{array}$ & 4,10 & Setuju \\
$\begin{array}{l}\text { Nilai-Nilai Sosial } \\
\left(\mathrm{X}_{2}\right)\end{array}$ & 3,96 & Setuju \\
$\begin{array}{l}\text { Pertimbangan } \\
\text { Pasar Kerja (X }\end{array}$ & 4,18 & Setuju \\
$\begin{array}{l}\text { Minat Mahasiswa } \\
\text { Akuntansi }\end{array}$ & 4,03 & Setuju \\
\hline
\end{tabular}

memilih karier

sebagai Akuntan

Publik (Y)

Sumber: Data diolah 2018

Berdasarkan Tabel tersebut, dapat disimpulkan bahwa jawaban responden untuk variabel penghargaan finansial yaitu memiliki nilai rata-rata skor tanggapan sebesar 4,10 dengan keterangan rata-rata responden menyatakan setuju dengan pernyataaan yang diajukan dalam kuesioneer. Jawaban responden untuk variable nilai-nilai sosial yaitu memiliki nilai rata-rata skor tanggapan sebesar 3,96 dengan keterangan rata-rata responden setuju dengan penryataan yang diajukan dalam kuesioner. Jawaban responden untuk variabel pertimbangan pasar kerja yaitu memiliki nilai rata-rata skor tanggapan sebesar 4,18 dengan keterangan rata-rata responden setuju dengan pernyataan ynag diajukan dalam kuesioner. Selanjutnya untuk variabel minat mahasiswa akuntansi memilih karier sebagai Akuntan Publik memiliki nilai rata-rata skor tanggapan sebesar 4,03 dengan keterangan rata-rata responden setuju dengan pernyataan yang diajukan dalam kuesioner. Sehingga dapat disimpulkan, rata-rata responden setuju bahwa penghargaan finansial, nilai-nilai sosial, dan pertimbangan pasar kerja akan mempengaruhi pemilihan karier sebagai Akuntan Publik pada mahasiswa S1 progran studi akuntansi Universitas Djuanda Bogor, Universitas Nusa Bangsa, Sekolah Tinggi Ilmu Ekonomi Triguna dan Universitas Pakuan.

Tabel 5: Rekapitulasi Uji Validitas

\begin{tabular}{lccc}
\hline \multicolumn{1}{c}{ Variabel } & rhitung & rkritis & $\begin{array}{c}\text { Kesimpul } \\
\text { an }\end{array}$ \\
\hline $\begin{array}{l}\text { Penghargaan } \\
\text { Finansial }\left(\mathrm{X}_{1}\right)\end{array}$ & 0,842 & 0,3 & Valid \\
$\begin{array}{l}\text { Nilai-Nilai Sosial } \\
\left(\mathrm{X}_{2}\right)\end{array}$ & 0,690 & 0,3 & Valid \\
$\left.\begin{array}{l}\text { Pertimbangan } \\
\text { Pasar Kerja (X }\end{array}\right)$ & 0,851 & 0,3 & Valid \\
$\begin{array}{l}\text { Minat Mahasiswa } \\
\text { Akuntansi }\end{array}$ & 0,853 & 0,3 & Valid \\
$\begin{array}{l}\text { Memilih Karier } \\
\text { Sebagai Akuntan }\end{array}$ & & & \\
Publik (Y) & & & \\
\hline
\end{tabular}


Sumber: Output pengolahan data dengan SPSS 22, 2018

Berdasarkan Tabel tersebut, hasilnya menunjukan bahwa dilihat dari skor ratarata variabel penghargaan finansial yaitu sebesar 0,842, variabel nilai-nilai sosial yaitu 0,690, variabel pertimbangan pasar kerja yaitu 0,851, dan variabel minat mahasiswa akuntansi memilih karier sebagai akuntan publik yaitu 0,853 , semuanya menunjukan nilai hitung yang lebih dari 0,3 sehingga dapat dinyatakan bahwa semua instrumen yang digunakan valid dan layak digunakan.

\begin{tabular}{lccc}
\multicolumn{4}{c}{ Tabel 6. Uji Reliabilitas } \\
\hline \multicolumn{1}{c}{ Variabel } & $\begin{array}{c}\text { Cronbach } \\
\text { Alpha }\end{array}$ & rkritis & $\begin{array}{c}\text { Kesimp } \\
\text { ulan }\end{array}$ \\
\hline $\begin{array}{l}\text { Penghargaan } \\
\text { Finansial }\left(\mathrm{X}_{1}\right)\end{array}$ & 0,795 & 0,6 & Reliabel \\
\hline $\begin{array}{l}\text { Nilai-Nilai } \\
\text { Sosial }\left(\mathrm{X}_{2}\right)\end{array}$ & 0,813 & 0,6 & Reliabel \\
\hline $\begin{array}{l}\text { Pertimbangan } \\
\text { Pasar Kerja } \\
\left(\mathrm{X}_{3}\right)\end{array}$ & 0,617 & 0,6 & Reliabel \\
\hline $\begin{array}{l}\text { Minat } \\
\text { Mahasiswa }\end{array}$ & 0,817 & 0,6 & Reliabel \\
Akuntansi & & & \\
Memilih & & & \\
Karier Sebagai \\
Akuntan \\
Publik (Y)
\end{tabular}

Hasil uji reliabilitas dari setiap item menunjukan bahwa variabel penghargaan finansial yaitu sebesar 0,795, variabel nilai-nilai sosial yaitu 0,813 , variabel pertimbangan pasar kerja yaitu 0,617 , dan variabel minat mahasiswa akuntansi memilih karier sebagai akuntan publik yaitu 0,817 , semua nilai tersebut menunjukan lebih besar atau sama dengan 0,6 sehingga semua instrumen yang digunakan dapat dikatakan reliabel, dan layak digunakan.

Berdasarkan uji statistik dapat disimpulkan bahwa grafik histogram memberikan pola distribusi yang normal dengan kurva berbentuk lonceng. Sedangkan grafik normal probability plots terlihat bahwa titik-titik tersebar disekitar garis diagonal, dengan penyebaran mengikuti arah garis diagonal. Dengan melihat grafik histogram normal probability plots tersebut dapat dikatakan bahwa model regresi sudah memenuhi asumsi normalitas sehingga data layak untuk digunakan, dan dapat disimpulkan bahwa data terdistribusi normal, dan model regresi sudah memenuhi asumsi normalitas. Selain itu pengujian normalitas data secara analisis statistik dapat dilakukan dengan menunjukan uji one sampel kolmogorov smirnow hasil pengujian one sampel kolmogorov smirnow nilai Asymp.Sig. (2 tailed) yaitu sebesar 0,200. Hal tersebut menunjukan bahwa data telah terdistribusi normal karena nilai Asymp.Sig. (2 tailed) lebih besar dari 0,05.

$$
\text { Pengujian Uji Multikolonieritas }
$$
dengan menggunakan metode Varian Inflation Factor memilki kriteria pengambilan keputusan nilai VIF harus kurang dari 10 (VIF < 10) dan memiliki nilai tolerance lebih dari 0,1 yang berarti tidak terjadi multikolonieritas. Berdasarkan uji statistik didapati bahwa ketiga variabel bebas mempunyai nilai VIF 1,434 untuk variabel penghargaan finansial, nilai-nilai sosial memiliki nilai VIF 1,749 , pertimbangan pasar kerja memiliki nilai VIF 1,368. Sedangkan, untuk nilai tolerance variabel penghargaan finansial sebesar 0,697, nilai-nilai sosial dengan nilai tolerance sebesar 0,572, pertimbangan pasar kerja mempunyai nilai tolerance sebesar 0,731. Ketiga variabel tersebut memiliki nilai VIF kurang dari 10 (VIF < 10) dan mempunyai nilai tolerance lebih dari 0,1 maka dapat disimpulkan bahwa model regresi tidak terjadi gejala multikolinieritas.

Pengujian Uji Heteroskedastisitas dengan menggunakan Uji Glejser. Adapun kriteria pengambilan keputusan Uji Glejser yaitu jika nilai signifikansi antara variabel independen dengan absolut residual > 0,05 maka tidak terjadi masalah heteroskesastisitas. Berdasarkan hasil pengujian Uji Glejser menunjukan variabel penghargaan finansial memiliki nilai Sig. sebesar 0,906, variabel nilai-nilai sosial 
memiliki nilai Sig. sebesar 0,559 , dan variabel pertimbangan pasar kerja memiliki nilai Sig. sebesar 0,088. Ketiga variabel tersebut memiliki nilai signifikansi > 0,05 , maka dapat disimpulkan bahwa model regresi tidak terjadi masalah heterokedastisitas.

Analisis regresi linear berganda digunakan untuk mengetahui hubungan fungsional antara beberapa variabel bebas secara bersama-sama terhadap variable terikat, dan juga untuk mengetahui jika nilai variabel dependen (Minat Mahasiswa Memilih Karier Sebagai Akuntan Publik) dinaikan atau diturunkan nilainya. Hasil analisis regresi linier berganda dapat dilihat pada Tabel 7 berikut ini:

Tabel 7. Analisis Regresi Linear Berganda

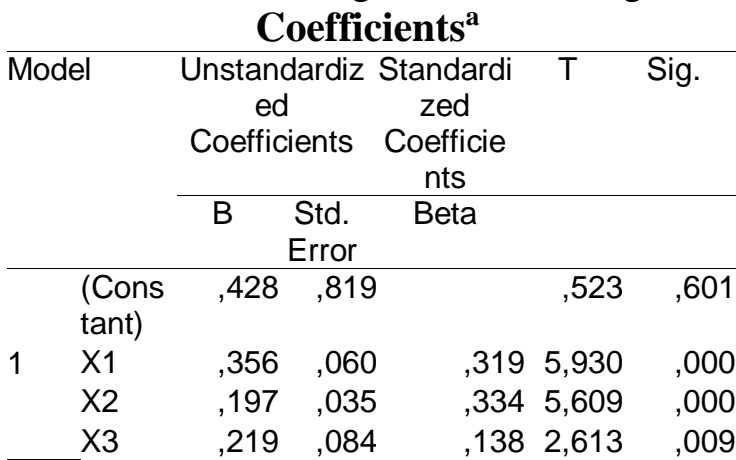

Sumber: Output pengolahan data dengan SPSS 22, 2018

Berdasarkan Tabel diatas diketahui bahwa nilai dari persamaan regresi yaitu sebagai berikut:

$$
\mathrm{Y}=\mathrm{a}+\beta_{1} \mathrm{X}_{1}+\beta_{2} \mathrm{X}_{2}+\beta_{3} \mathrm{X}_{3}+\varepsilon
$$

$\mathrm{Y}=0,428+0,356 \mathrm{X}_{1}+0,197 \mathrm{X}_{2}+0,219 \mathrm{X}_{3}+\varepsilon$

Interprestasi dari regresi tersebut yaitu sebagai berikut :

1. Hasil persamaan regresi tersebut diperoleh nilai konstanta sebesar 0,428, nilai tersebut mempunyai arti bahwa jika semua variabel bebas yaitu penghargaan finansial, nilai-nilai sosial dan pertimbangan pasar kerja bernilai 0 , maka Minat Mahasiswa Memilih Karier Sebagai Akuntan Publik bernilai 0,428 atau nilai pemilihan profesi akuntan publik tetap.

2. Hasil persamaan regresi untuk variabel penghargaan finansial sebesar 0,356. Hal tersebut menunjukan bahwa untuk setiap peningkatan variabel penghargaan finansial sebesar satu satuan, dengan asumsi variabel nilainilai sosial dan pertimbangan pasar kerja bernilai 0 , maka menyebabkan meningkatnya Minat Mahasiswa Memilih Karier Sebagai Akuntan Publik sebesar 0,356.

3. Hasil persamaan regresi untuk variabel nilai-nilai sosial sebesar 0,197. Hal tersebut menunjukan bahwa untuk setiap peningkatan variabel nilai-nilai sosial sebesar satu satuan, dengan asumsi variabel penghargaan finansial dan pertimbangan pasar kerja bernilai 0 , maka menyebabkan meningkatnya Minat Mahasiswa Memilih Karier Sebagai Akuntan Publik sebesar 0,197.

4. Hasil persamaan regresi untuk variabel pertimbangan pasar kerja sebesar 0,219. Hal tersebut menunjukan bahwa untuk setiap peningkatan variabel pertimbangan pasar kerja sebesar satu satuan, dengan asumsi variabel penghargaan finansial dan nilai-nilai sosial bernilai 0 , maka menyebabkan meningkatnya Minat Mahasiswa Memilih Karier Sebagai Akuntan Publik sebesar 0,219.

Tabel 8.Koefisien Korelasi Berganda Model Summary ${ }^{b}$

\begin{tabular}{lrrrr}
\hline $\begin{array}{l}\text { Mod } \\
\text { el }\end{array}$ & $R$ & $\begin{array}{c}\mathrm{R} \\
\text { Square }\end{array}$ & $\begin{array}{c}\text { Adjusted R } \\
\text { Square }\end{array}$ & $\begin{array}{c}\text { Std. Error of the } \\
\text { Estimate }\end{array}$ \\
\hline 1 &, $652^{\mathrm{a}}$ &, 425 &, 419 & 1,445 \\
\hline \multicolumn{4}{l}{$\begin{array}{l}\text { Sumber: } \\
\text { Output }\end{array}$} \\
2018
\end{tabular}

Berdasarkan Tabel tersebut, diperoleh nilai $\mathrm{R}$ sebesar 0,652 yang menunjukan bahwa nilai $R(0,652)$ tersebut berada pada interval nilai $\mathrm{R}(0,601-0,800)$ dengan derajat kekuatan hubungan yang kuat, sehingga terdapat pengaruh yang kuat antara penghargaan finansial, nilainilai sosial, dan pertimbangan pasar kerja terhadap minat mahasiwsa akuntansi memilih karier sebagai akuntan publik. Hal tersebut berarti bahwa semakin baik penghargaan finansial, nilai-nilai sosial, dan pertimbangan pasar kerja maka semakin meningkatkan minat 
mahasiswaakuntansi memilih karier sebagai akuntan publik.

Sedangkan berdasarkan tingkat korelasi parsial (partial correlation) antara penghargaan finansial dengan minat mahasiswa akuntansi memilih karier sebagai akuntan publik yaitu sebesar 0,561 $(56,1 \%)$ yang menyatakan bahwa korelasinya cukup kuat, antara nilai-nilai sosial dengan minat mahasiswa akuntansi memilih karier sebagai akuntan publik yaitu sebesar $0,555(55,5 \%)$ menyatakan bahwa korelasinya cukup kuat, antara pertimbangan pasar kerja dengan minat mahasiswa akuntansi memilih karier sebagai akuntan publik yaitu sebesar 0,412 $(41,2 \%)$ yang menyatakan bahwa korelasinya cukup kuat.

Tabel 9. Koefisien Determinasi $\mathrm{R}^{2}$ Model Summary ${ }^{b}$

\begin{tabular}{lrrrr}
\hline $\begin{array}{l}\text { Mod } \\
\text { el }\end{array}$ & $R$ & $\begin{array}{c}\mathrm{R} \\
\text { Square }\end{array}$ & $\begin{array}{c}\text { Adjusted } \mathrm{R} \\
\text { Square }\end{array}$ & $\begin{array}{c}\text { Std. Error of the } \\
\text { Estimate }\end{array}$ \\
\hline 1 &, $652^{\mathrm{a}}$ &, 425 &, 419 & 1,445 \\
\hline \multicolumn{4}{l}{$\begin{array}{l}\text { Sumber: Output pengolahan data dengan SPSS 22, } \\
2018\end{array}$}
\end{tabular}

Berdasarkan Tabel diatas, diperoleh R2 ( $R$ Square) sebesar 0,425 atau $(42,5 \%)$. Hal ini menunjukan bahwa kontribusi penghargaan finansial, nilainilai sosial, dan pertimbanganpasar kerja terhadap minat mahasiswa akuntansi memilih karier sebagai akuntanpublik yaitu sebesar $42,5 \%$, sedangkan sisanya $57,5 \%$ dipengaruhi atau dijelaskan oleh variabel lain yang tidak dimasukan dalam model penelitian ini seperti gender, lingkungan kerja, pelatihan profesional, pengakuan professional dan personalitas.

\begin{tabular}{lccccc}
\multicolumn{6}{c}{ Tabel 10.Uji F } \\
\hline \multicolumn{5}{c}{ ANOVA $^{\text {a }}$} \\
\hline Model & $\begin{array}{c}\text { Sum of } \\
\text { Squares }\end{array}$ & Df & $\begin{array}{c}\text { Mean } \\
\text { Square }\end{array}$ & F & Sig. \\
\hline $\begin{array}{l}\text { Regre } \\
\text { ssion }\end{array}$ & 438,719 & 3 & 146,240 & 70,045 &, $000^{\text {b }}$ \\
$\begin{array}{l}\text { Resid } \\
\text { ual }\end{array}$ & 592,934 & 284 & 2,088 & & \\
Total & 1031,653 & 287 & & &
\end{tabular}

Sumber: Output pengolahan data dengan SPSS 22, 2018

Berdasarkan Tabel tersebut dapat diketahui bahwa hasil pengujian menggunakan uji $\mathrm{F}$, diperoleh nilai $\mathrm{F}_{\text {hitung }}$ sebesar 70,045, sedangkan nilai $F_{\text {tabel }}$ sebesar 2,64. Apabila $F_{\text {hitung }}$ dibandingkan dengan $F_{\text {tabel }}$, maka $F_{\text {hitung }}>F_{\text {tabel }}(70,045>$ 2,64) dengan nilai signifikansi $F$ sebesar $0,00<0,05$. Hal ini berarti bahwa $\mathrm{H}_{\mathrm{o}}$ ditolak dan $\mathrm{H}_{\mathrm{a}}$ diterima. Kondisi ini bermakna bahwa penghargaan finansial, nilai-nilai sosial dan pertimbangan pasar kerja memiliki pengaruh secara smultan terhadap minat mahasiswa akuntansi memilih karier sebagai akuntan publik.

\section{Tabel 11. Uji t}

Coefficients $^{\mathbf{a}}$

\begin{tabular}{|c|c|c|c|c|c|c|}
\hline \multirow{2}{*}{\multicolumn{2}{|c|}{ Model }} & \multicolumn{2}{|c|}{$\begin{array}{l}\text { Unstandardize } \\
\text { d Coefficients }\end{array}$} & $\begin{array}{l}\text { Standardi } \\
\text { zed } \\
\text { Coefficie } \\
\text { nts }\end{array}$ & \multirow[t]{2}{*}{ T } & \multirow[t]{2}{*}{ Sig. } \\
\hline & & B & $\begin{array}{l}\text { Std. } \\
\text { Error }\end{array}$ & Beta & & \\
\hline & $\begin{array}{l}\text { (Cons } \\
\text { tant) }\end{array}$ & ,428 & ,819 & & ,523 & ,601 \\
\hline 1 & X1 & ,356 & ,060 & 319 & 5,930 &, 000 \\
\hline & $\mathrm{X} 2$ & , 197 & ,035 & ,334 & 5,609 & ,000 \\
\hline & X3 & ,219 & ,084 & ,138 & 2,613 & ,009 \\
\hline
\end{tabular}

Sumber: Output pengolahan data dengan SPSS 22, 2018

Berdasarkan Tabel tersebut dapat diketahui bahwa:

1. Uji t Variabel Penghargaan Finansial

Hasil pengujian dengan menggunakan uji $\mathrm{t}$ diperoleh nilai $\mathrm{t}_{\mathrm{hitung}}$ untuk penghargaan finansial sebesar 5,930, sedangkan nilai $t_{\text {tabel }} 1,968$. Apabila thitung dibandingkan dengan $t_{\text {tabel }}$ maka $t_{\text {hitung }}>$ $\mathrm{t}_{\text {tabel }}(5,930>1,968)$ dengan tingkat signifikan $0.000<0.05$. Hal tersebut berarti bahwa $\mathrm{H}_{\mathrm{o}}$ ditolak dan $\mathrm{H}_{\mathrm{a}}$ diterima. Kondisi ini bermakna bahwa penghargaan finansial secara parsial berpengaruh terhadapminat mahasiswa akuntansi memilih karier sebagai akuntan publik.

2. Uji t Variabel Nilai-Nilai Sosial

$$
\text { Hasil pengujian dengan }
$$

menggunakan $u j i \mathrm{t}$ diperoleh nilai $t_{\text {hitung }}$ untuk nilai-nilai sosial sebesar 5,609, sedangkan nilai $t_{\text {tabel }} 1,968$. Apabila $t_{\text {hitung }}$ dibandingkan dengan $t_{\text {tabel }}$ maka $t_{\text {hitung }}>$ $t_{\text {tabel }}(5,609>1,968)$ dengan tingkat signifikan $0.000<0.05$. Hal ini berarti bahwa $\mathrm{H}_{\mathrm{o}}$ ditolak dan $\mathrm{H}_{\mathrm{a}}$ diterima. Kondisi ini bermakna bahwa nilai-nilai sosial 
secara parsial berpengaruh terhadapminat mahasiswa akuntansi memilih karier sebagai akuntan publik.

3. Uji t Variabel Pertimbangan Pasar Kerja

Hasil pengujian dengan menggunakan uji $\mathrm{t}$ diperoleh nilai $\mathrm{t}_{\text {hitung }}$ untuk pertimbangan pasar kerja sebesar 2,613, sedangkan nilai $t_{\text {tabel }} 1,968$. Apabila $t_{\text {hitung }}$ dibandingkan dengan $t_{\text {tabel }}$ maka $t_{\text {hitung }}$ $>t_{\text {tabel }}(2,613>1,968)$ dengan tingkat signifikan $0.009<0.05$. Hal ini berarti bahwa $\mathrm{H}_{\mathrm{o}}$ ditolak dan $\mathrm{H}_{\mathrm{a}}$ diterima. Kondisi ini bermakna bahwa pertimbangan pasar kerja secara parsial berpengaruh terhadap minatmahasiswa akuntansi memilih karier sebagai akuntan publik.

\section{KESIMPULAN DAN SARAN KESIMPULAN}

Berdasarkan hasil pengujian, pengolahan dan juga analisis data yang telah dilakukan serta pembahasan yang telah dijelaskan, serta tujuan penelitian ini yaitu untuk mengetahui pengaruh penghargaan finansial, nilai-nilai sosial dan pertimbangan pasar kerja terhadap minat pemilihankarier sebagai akuntan publik (studi empiris pada mahasiswa $\mathrm{S} 1$ program studi akuntansi perguruan tinggi swasta di Bogor), maka dapat diambil kesimpulan dari hasil penelitian tersebut yaitu sebagai berikut:

1. Variabel penghargaan finansial, nilainilai sosial dan pertimbangan pasar kerja berpengaruh secara simultan terhadap minat mahasiswaakuntansi memilih karier sebagai akuntan publik.

2. Variabel penghargaan finansial secara parsial berpengaruh terhadap minat mahasiswa akuntansi memilih karier sebagai akuntan publik.

3. Variabel nilai-nilai sosial secara parsial berpengaruh terhadap minat mahasiswa akuntansi memilih karier sebagai akuntan publik.

4. Variabel pertimbangan pasar kerja secara parsial berpengaruh terhadap minat mahasiswa akuntansi memilih karier sebagai akuntan publik.

\section{SARAN}

Berdasarkan hasil dari penelitjan dan kesimpulan ynag sudah diuraikan sebelumnya, maka selanjutnya peneliti memberikan saran untuk beberapa pihak diantaranya sebagai berikut:

1. Bagi akademisi, untuk lebih meningkatakan mutu kualitas lulusan sebagai pekerja yang siap bekerja, maka perlu diupayakan keseragaman kurikulum dengan memberikan mata kuliah konsentrasi lebih dini kepada para mahasiswa sehingga mereka punya visi yang lebih baik dalam menentukan profesi apa yang akan digelutinya selepas kuliah nanti.

2. Bagi penelitian selanjutnya disarankan untuk menambahkan sampelpenelitian dengan mengambil sampel mahasiswa akuntansi dari perguruan tinggi negeri dan juga swasta yang lain. Hal ini diperlukan untuk meningkatkan akurasi hasil yang diperoleh dimasa yang akan datang dapat lebih sempurna dari penelitian ini.

3. Bagi peneliti selanjutnya juga disarankan untuk lebih mengembangkan penelitian ini dengan cara meneliti faktor-faktor lain yang memiliki pengaruh terhadap pemilihan karier sebagai akuntanpublik yang tidak diteliti oleh peneliti. Seperti motivasi kepribadian individu, lingkungan kerja, gender, pelatihan profesional, pengakuan professional dan personalitas. 
DAFTAR PUSTAKA

Arismutia, S. A. (2017). Pengaruh

Penghargaan Finansial dan Pertimbangan Pasar Kerja Terhadap Minat Mahasiswa Akuntansi Untuk Berkarir Menjadi Akuntan Publik. EJurnal STIE INABA, 16(2), 1-23.

Dary, A. W., \& Ilyas, F. (2017). Pengaruh Gender, Penghargaan Finansial dan Pertimbangan Pasar Kerja Terhadap Minat Mahasiswa Akuntansi Untuk Berkarir Menjadi Akuntan Publik dan Non Akuntan Publik. Jurnal Akuntansi, 7(1), 51-60.

Harianti, S. S. (2017). Pengaruh Penghargaan Finansial, Pertimbangan Pasar Kerja Dan Lingkungan Keluarga Terhadap Minat Menjadi Akuntan Publik (Studi Empiris Mahasiswa S1 Akuntansi Universitas Negeri dan Swasta Kota Padang). Jurnal Akuntansi, 5(1).

Hikmah, J. S., \& Samsul, R. (2020). Faktor-Faktor Yang Menentukan Keputusan Mahasiswa Memilih Jurusan Akuntansi Syariah (Doctoral dissertation, IAIN SURAKARTA).

Iswahyuni, Y. (2018). Analisis FaktorFaktor Yang Mempengaruhi Pemilihan Karir Menjadi Akuntan Publik Oleh Mahasiswa Program Studi Akuntansi Stie Aka Semarang. JAK (Jurnal Akuntansi): Kajian Ilmiah Akuntansi, 5(1), 33-44.

Kharismawati, H. (2015). Analisis Pengaruh Penghargaan Finansial,
Pelatihan Profesional Pengakuan Profesional, Nilai-Nilai Sosial Dan Lingkungan Kerja Terhadap Pemilihan Karir Akuntan Publik (Studi Empiris pada Mahasiswa PPAK di UNS, UGM dan STIE YKPN) (Doctoral dissertation, Universitas Muhammadiyah Surakarta).

Kurniawan, Adhitya Reza dan Zulaikha, 2015, Pengaruh MotivasiKarier, MotivasiEkonomi, Dan Motivasi Gelar Terhadap Mlnat Mahasiswa Akuntansi Mengikuti PendidikanProfesi Akuntansi, Diponegoro Journal Of Accounting Volume 4, Nomor 1, Universitas Diponegoro, Semarang.

Kusuma, I. C., \& Rizki, L. M. (2017). Pengaruh Intelegence Quotient (IQ), Emotional Quotient (EQ), Dan Spiritual Quotient (SQ) Terhadap Pemahaman Akuntansi Siswa Di Smk Sumpah Pemuda 2. JURNAL AKUNIDA, 3(1), 29-39.

Kwarto, F., \& Saputra, H. (2017) FaktorFaktor Yang Mempengaruhi Pemilihan Karir Sebagai Akuntan Profesional Berdasarkan Pmk No. 25/Pmk. 01/2014 Dalam Menghadapi Asean Economic Community (Aec) Dengan Kepercayaan Diri (Self Efficacy) Sebagai Variabel Moderasi.

Marsudi, J., \& Gustiani, D. S. (2018). Pengaruh Minat Belajar Ketersediaan Sarana Pendidikan Dan Kompetensi Dosen Terhadap Pemahaman Psak Konvergensi. JURNAL AKUNIDA, 4(1), 21-34. 
Mulyaningsih, M. (2018, September). The Effect On Implementation Of Public Accountant Professions Act On The Interest Of Students Being Public Accountants (Case Study In Pakuan University). In PROCEEDINGS (Vol. 1, No. 1).

Purwati, A. S., \& Sari, Y. Y. (2015).

Persepsi Mahasiswa Akuntansi

Terhadap Pemilihan Karier (Studi Kasus Pada Mahasiswa S1

Akuntansi Reguler Perguruan

Tinggi Negeri dan Swasta di

Kota

Purwokerto). AKUNTABEL, 5(2).

Rindani, Annisa, 2015, FaktorFaktor Yamg Mempengaruhi Minat Mahasiswa Akuntansi Untuk Berkarir Sebagai AkuntanPublik (Studi Kasus pada PerguruanTinggi dengan Program Studi Akuntansi yang Berakreditasi B yang terdapat di Pekanbaru), Jom FEKON Vol. 2 No. 2, Faculty of Economic Riau University, Pekanbaru, Indonesia.

Sandy, R. K. (2019). Faktor-Faktor Yang Mempengaruhi Minat Mahasiswa Berkarir Di Perbankan Syariah (Studi Empiris Pada Mahasiswa Akuntansi Universitas Muhammadiyah

Magelang) (Doctoral dissertation, Skripsi, Universitas Muhammadiyah Magelang).

Senjari, R., Hasan, A., \& Sofyan, A. (2016). Pengaruh Motivasi, Lingkungan Kerja Dan Nilai Sosial Terhadap Minat Mahasiswa Akuntansi Dalam Memilih Karir Sebagai Akuntan Publik (Doctoral dissertation, Riau University).
Senjari, Richa, 2016, Pengaruh Motlvasi, LingknganKerja Dan NilaiSosial Terhadap Minat Mahasiswa Akuntansi Dalam Memilih Karir Sebagai AkuntanPublik, JOM FEKON VOL. 3, No. 1, Department of Accounting, Faculty of Economics Riau University, Pekanbaru.

Supriyono, R.A. 2017, Akuntansi Keprilakuan, Grasindo dengan Gadjah Mada University Press, Jakarta.

Triwidatin, Y. (2019). Kajian Terhadap Siswa Akuntansi Atas Motivasi Belajar, Kepedulian Orang Tua Dan Prestasi Belajar. JURNAL AKUNIDA, 4(2), 15-30.

Undang-Undang Republik Indonesia Nomor 5 Tahun 2011 tentang Akuntan Publik.

Widyanti, R., \& Saputra, D. (2018). Pengaruh Penghargaan Finansial, Pertimbangan Pasar Kerja Dan Lingkungan Keluarga Terhadap Minat Menjadi Akuntan Publik (Studi Empiris Mahasiswa S1 Akuntansi Universitas Ekasakti). Jurnal Menara Ekonomi: Penelitian dan Kajian Ilmiah Bidang Ekonomi, 4(2).

Zotorvie, Justice Stephen Tetteh, 2016, Determinants of Carer Choice among Students of Institut of Chartered Accountants (Ghana), European Scientific Journal, November 2016 edition, vol.12,No.31 ISSN:1857 - 7881. (URL:http://dx.doi.org/10.19044/es j.2016.v12n31p255).

https://bogorkota.bps.go.id/ http://iapi.or.id/Iapi/detail. www.forlap.ristekdikti.go.id/ 
www.iaiglobal.or.id

www.id.m.wikipedia.org

www.ojk.go.id/

www.pppk.kemenkeu.go.id/

www. setjen.kemenkeu.go.id/content/ppajp.

html 